\title{
伝達関数補間を用いた評価点移動時の能動騒音制御*
}

\author{
奥 山智 尚*1, 松 久 寛 ${ }^{* 2}$ \\ 宇津野秀夫*2, 朴正圭*2
}

\section{Active Noise Control for a Moving Evaluation Point Using Transfer Function Interpolation}

\author{
Tomonao OKUYAMA*3, Hiroshi MATSUHISA, \\ Hideo UTSUNO and Jeong Gyu PARK \\ ${ }^{* 3}$ Department of Precision Engineering, Kyoto University, \\ Yoshida-Honmachi, Sakyo-ku, Kyoto-shi, Kyoto, 606-8501 Japan
}

\begin{abstract}
In active noise control (ANC), the transfer function of the error path (TFEP) changes when the evaluation point moves, and it causes a bad performance of noise control. In this study, a new method to identify TFEP at an arbitrary point are proposed. This method is based on the plane wave theory, and the impulse response of TFEP is derived analytically as a function of the position, using measured impulse responses at two points. Applying this method to update the compensation filter of the varying TFEP in a test tube, it is verified by the experiment that the noise can be suppressed significantly without divergence.
\end{abstract}

Key Words : Noise Control, Adaptive Control, Digital Control, Sound, Moving Evaluation Point, Transfer Function, Impulse Response, Interpolation, Identification

\section{1. 粕 言}

人間の社会生活において, 騒音問題とその対策は常 に大きな関心が寄せられている. 特に騒音と同振幅・ 逆位相の音を制御音源から出す事により騷音を打ち消 す能動騒音制御は，近年急速に研究が進み，一部では 実用化されている. しかし, 従来の研究の多くが騒音 源・制御音源・受音点の 3 者の位置が固定された条件 を前提としており，音源や受音点が移動する場合につ いての研究例は少ない.

受音点が移動する場合についての能動騷音制御の最 も基本的なモデルを図 1 に示す．音源や受音点が移動 しない場合の適応制御には一般に Filtered-X LMS アル ゴリズム(1)が用いられる。このアルゴリズムでは制御 音源への制御信号出力 $V_{\mathrm{c}}$ と受音点からの誤差信号入 力 $V_{\mathrm{e}}$ 間の伝達関数（誤差経路伝達関数）は不変とし ている為に, 受音点の移動に伴い誤差経路伝達関数が 変化する現象に対しては有効な制御を行なえない.

伝達関数の変化を考慮した能動騒音制御として, 口 バスト性を有するフィードバック制御器を用いた佐野 $ら^{(2)}$ 及び中井ら ${ }^{(3)}$ の研究があるが, 受音点の移動に伴

$*$ 原稿受付 2004 年 12 月 20 日.

*1 准員, 京都大学大学院工学研究科 -606-8501 京都市左京 区吉田本町)

*2 正員, 京都大学大学院工学研究科.

E-mail : tomonao@t01okuyama.mbox.media.kyoto-u.ac.jp

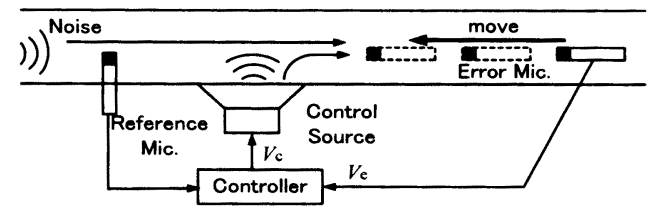

Fig. 1 Active noise control with moving error microphone.

う誤差経路伝達関数の大きな変化には追従できない． また, 小池ら(4)(5)の研究では誤差経路伝達関数を実時 間同定し，得た值を主系の補償フィルタに用いている が, 変化に追従できる計算速度に限界がある為, 移動 速度の増加に従い消音性能が低下する事が報告されて いる. これらの研究ではいずれも, 誤差経路伝達関数 を未知の值として捉えているが，制御対象とする 1 次 元の音響系においては誤差経路伝達関数は受音点位置 の関数として，あらかじめ求めておく事が可能である。 そこで本研究では受音点のみが移動する 1 次元音響 系において, 制御音源と受音点間の伝達関数を受音点 位置に依存する既知の值として与えることで, 受音点 の移動速度に制限を受けない能動騒音制御が可能とな ることを示す.この場合, 数䇢所での測定値から任意 の受音点位置での伝達関数を求める方法として, イン パルス応答を用いた新しい伝達関数補間法を提案する. 


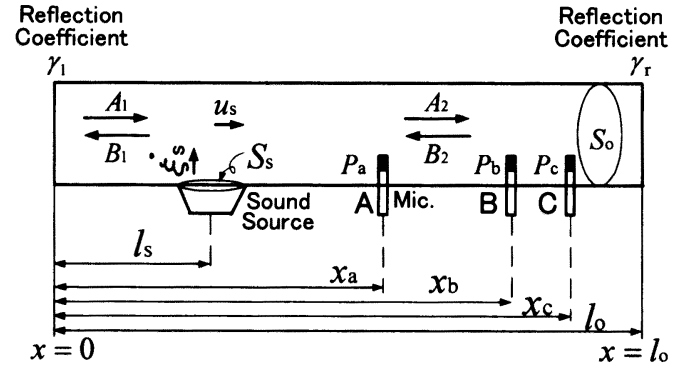

Fig. 2 1-dimensional acoustic tube system.

2. インパルス答を用いた 伝達関数補间

2.1 インピーダンス境界を有する 1 次元音境の伝迬関 数 図 2 に示す断面積 $S_{0}$, 全長 $l o$ の音響管において, $l_{\mathrm{s}}$ の位置に断面積 $S_{\mathrm{s}}$, 振動速度 $\dot{\xi}_{\mathrm{s}}$ の音源を配置した時 の任意の位置 $x$ における音圧 $P$ を求める．音響管中を 伝わる音波を平面波と仮定すると, 音場内の速度ポテ ンシャルのは次の波動方程式を満たす. なお $c$ は音速 である.

$$
\frac{\partial^{2} \Phi}{\partial t^{2}}=c^{2} \frac{\partial^{2} \Phi}{\partial x^{2}}
$$

音圧 $P$ およひ粒子速度 $u$ は $\Phi$ を用いてそれぞれ

$$
\begin{aligned}
& P=\rho \frac{\partial \Phi}{\partial t} \\
& u=-\frac{\partial \Phi}{\partial x}
\end{aligned}
$$

と表される。ただし平面波の仮定は音源の近傍 $\left|l_{s}-x\right|<\varepsilon$ では成立しないことに注意する必要がある. $\varepsilon$ の大きさは音響管の断面寸法の約半分である(の). 受 音点位置 $x$ における $\Phi$ の解は $0 \leq x \leq l_{\mathrm{s}}-\varepsilon$ において

$$
\Phi_{1} e^{j \omega t}=\left(A_{1} e^{-j k x}+B_{1} e^{j k x}\right) e^{j \omega t}
$$

となり, $l_{\mathrm{s}}+\varepsilon \leq x \leq l \circ$ において

$$
\Phi_{2} e^{j \omega t}=\left(A_{2} e^{-j k x}+B_{2} e^{j k x}\right) e^{j \omega t}
$$

となる.ここで $e^{-j k x}$ は進行波を， $e^{j k x}$ は後退波を示し， $\omega$ は角振動数, $k$ は波数 $\omega / c$ を示す. また $A_{1}, B_{1}$, $A_{2} ， B_{2}$ は境界条件によって決定される係数である. 境界条件は左右端の複素反射率がそれぞれ $\gamma_{1}, \gamma_{\mathrm{r}}$, $x=l_{\mathrm{s}}$ においても平面波の仮定が成立するとしたとき の体積速度の釣合いが

$$
S_{\mathrm{o}} \rho\left\{\frac{\partial \Phi_{2}\left(l_{\mathrm{s}}\right)}{\partial x}-\frac{\partial \Phi_{1}\left(l_{\mathrm{s}}\right)}{\partial x}\right\}=S_{\mathrm{s}} \dot{\xi}_{\mathrm{s}}
$$

Table. 1 Values of parameters used in simulation.

\begin{tabular}{c|c}
\hline Sampling Frequency $f_{\mathrm{s}}$ & $2.56 \times 10^{3} \mathrm{~Hz}$ \\
\hline Sampling Time $\Delta t$ & $3.91 \times 10^{-4} \mathrm{~s}$ \\
\hline Sampling Number $N$ & 2048 \\
\hline$l_{\mathrm{o}}$ & $5.20 \mathrm{~m}$ \\
\hline$l_{\mathrm{s}}$ & $1.10 \mathrm{~m}$ \\
\hline$x_{\mathrm{a}}$ & $2.25 \mathrm{~m}$ \\
\hline$x_{\mathrm{b}}$ & $2.76 \mathrm{~m}$ \\
\hline$x_{\mathrm{c}}$ & $3.27 \mathrm{~m}$ \\
\hline Tuberadius $r$ & $5.35 \times 10^{-2} \mathrm{~m}$ \\
\hline$\varphi$ & 0.49 \\
\hline$\rho$ & $1.19 \mathrm{~kg} / \mathrm{m}^{3}$ \\
\hline$c$ & $340 \mathrm{~m} / \mathrm{s}$ \\
\hline$\gamma_{\mathrm{l}}$ & $6.00 \times 10^{-1}$ \\
\hline
\end{tabular}

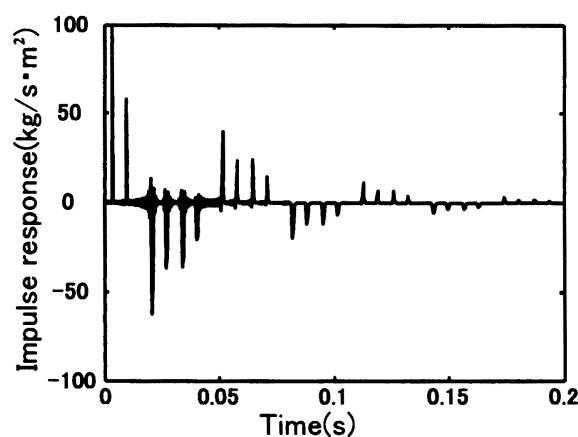

Fig. 3 Impulse response between $\dot{\xi}$ s and $P$

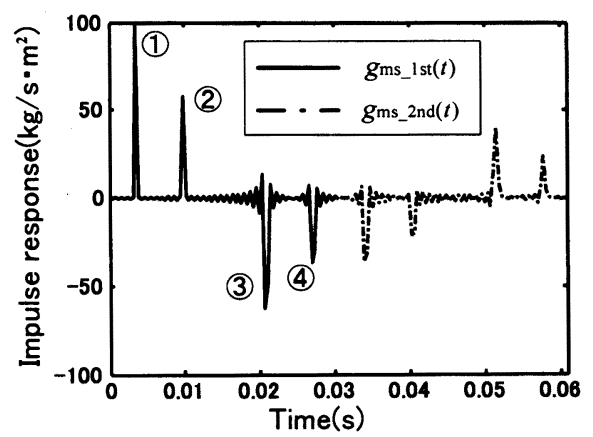

Fig. 4 The enlarged time data of the first 8 impulses.

である. 従って, 音圧 $P=\rho(\partial \Phi / \partial t)$ は $0 \leq x \leq l_{\mathrm{s}}-\varepsilon$ で

$$
\begin{array}{r}
P=\frac{\rho c \varphi}{2} \dot{\xi}_{\mathrm{s}}\left(e^{-j k\left(l_{\mathrm{s}-x}\right)}+\gamma_{1} e^{-j k\left(l_{\mathrm{s}}+x\right)}+\gamma_{\mathrm{r}} e^{-j k\left(2 l_{0}-x-l_{\mathrm{s}}\right)}\right. \\
\left.+\gamma_{1} \gamma_{\mathrm{r}} e^{-j k\left(2 l_{0}+x-l_{\mathrm{s}}\right)}\right) /\left(1-\gamma_{1} \gamma_{\mathrm{r}} e^{-2 j k l 0}\right)
\end{array}
$$

$l_{\mathrm{s}}+\varepsilon \leq x \leq l_{0}$ で 


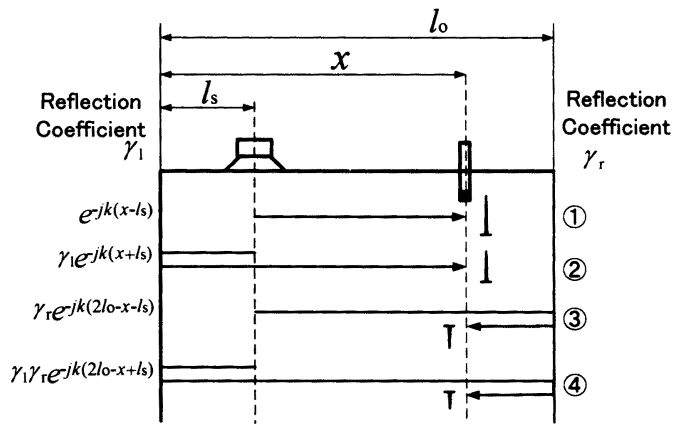

Fig. 5 Acoustic paths from speaker to the microphone.

$$
\begin{array}{r}
P=\frac{\rho c \varphi}{2} \dot{\xi}_{\mathrm{s}}\left(e^{-j k(x-/ \mathrm{s})}+\gamma_{\mathrm{l}} e^{-j k(x+l \mathrm{~s})}+\gamma_{\mathrm{r}} e^{-j k(2 / \mathrm{o}-x-/ \mathrm{s})}\right. \\
\left.+\gamma_{\mathrm{l}} \gamma_{\mathrm{r}} e^{-j k\left(2 l^{-}-x+l_{\mathrm{s}}\right)}\right) /\left(1-\gamma_{\mathrm{l}} \gamma_{\mathrm{r}} e^{-2 j k l o}\right)
\end{array}
$$

となる.ここで， $\varphi$ は音響管断面積 $S$ 。 と音源断面積 $S_{\mathrm{s}}$ の比 $S_{\mathrm{s}} / S_{\mathrm{o}}, \rho$ は空気密度である. このとき音源表 面の振動速度 ・受音点音圧間の伝達関数 $G_{\mathrm{m}}=P / \dot{\xi}$ ：は 両端での無限回の反射を考慮すると $l_{s}+\varepsilon \leq x \leq l_{0}$ で

$$
\begin{aligned}
G_{\mathrm{ms}}=\frac{\rho c \varphi}{2} & \left(e^{-j k(x-l \mathrm{~s})}+\gamma_{1} e^{-j k(x+l \mathrm{~s})}+\gamma_{\mathrm{r}} e^{-j k\left(2 l_{0}-x-l \mathrm{~s}\right)}\right. \\
& \left.+\gamma_{1} \gamma_{\mathrm{r}} e^{-j k(2 l o-x+l \mathrm{~s})}\right) \times \sum_{n=0}^{\infty}\left(\gamma_{1} \gamma_{\mathrm{r}} e^{-2 j \omega l o / c}\right)^{n}
\end{aligned}
$$

という無限級数の総和の形で表される. 式(9)の伝達関 数を逆フーリエ変換して得られるインパルス応答 $g_{\mathrm{ms}}(t)$ の波形を図 3 に, $0 \leq t \leq 4 l_{0} / c$ の拡大図を図 4 に示す.なお計算には表 1 に示す各諸元を用い, $x=x_{\mathrm{a}}$ とした， $\gamma_{1}$ は吸音性を有する閉鎖端を模してい る. また $\gamma_{\mathrm{r}}$ は

$$
\begin{aligned}
\gamma_{\mathrm{r}}= & |R| \exp (j-2 k \delta) \\
\delta / r & =0.613-0.117(k r)^{2}, \quad k r<0.5 ; \\
\delta / r= & 0.639-0.110(k r)^{2}, \quad 0.5<k r<1.2 ; \\
|R|= & 0.0133 k r-0.591(k r)^{2} \\
& +0.336(k r)^{3}-0.0643(k r)^{4}
\end{aligned}
$$

として開放端を模した.

$g_{\mathrm{ms}}(t)$ は 1 往復時間 $2 l_{0} / c=3.08 \times 10^{-2}(s)$ に含まれる 4 個のインパルス波形を基本に，両端の反射率に従つ て減衰するインパルス列である.この $2 l o / c$ 毎の波形 の繰り返しは式(9)右辺の無限級数総和の項に対応し, 従って図 4 のインパルス(1)は式(9)右辺の第 1 項に対応 し，音源から右側に進むインパルスを（図 5110経 路）を示す. 同様にインパルス(2)は式(9)右辺の第 2 項 に対応し, 音源から一旦左側に進み左端で反射した後 右方向に進むインパルスを（図 5(2)の経路），インパ ルス(3)は式(8)右辺の第 3 項に対応し, 音源から一旦右 側に進み右端で反射した後左方向に進むインパルスを

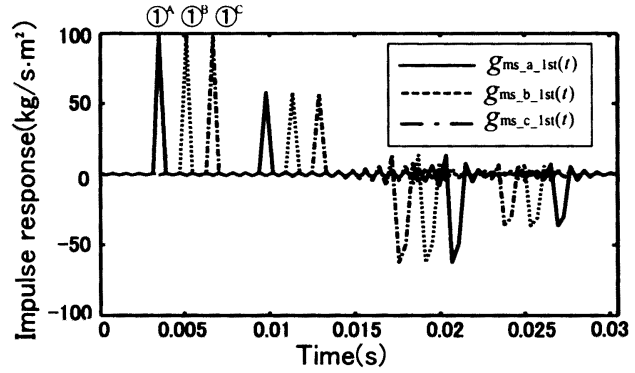

Fig. 6 Impulse responses at point A, B and C (Simulation).

（図 5(3)の経路），インパルス(4)は式(9)右辺の第4 項 に対応し, 第 2 項のインパルスが右端で反射した後左 方向に進むもの（図 5(4)の経路）を示す(7). 以下では 最初の 4 個のインパルスに対応する式(9)右辺の 4 項を まとめて

$$
\begin{aligned}
G_{\mathrm{ms}_{-} 1 \mathrm{st}}= & \frac{\rho c \varphi}{2}\left(e^{-j k(x-/ \mathrm{s})}+\gamma_{1} e^{-j k(x+/ \mathrm{s})}\right. \\
& \left.+\gamma_{\mathrm{r}} e^{-j k(2 / 0-x-/ \mathrm{s})}+\gamma_{1} \gamma_{\mathrm{r}} e^{-j k(2 / 0-x+/ \mathrm{s})}\right)
\end{aligned}
$$

と表す。

\section{2 インパルス応答を用いた伝達関数補间法の原理}

式(9)の伝達関数 $G \mathrm{~ms}$ は式(14)の $G_{\mathrm{ms} \text { _ }_{-} \text {1st }}$ を用いて

$$
G_{\mathrm{ms}}=G \mathrm{~ms}_{-} \text {st } \times \sum_{n=0}^{\infty}\left(\gamma_{1} \gamma_{\mathrm{r}} e^{-2 j \omega l o / c}\right)^{n}
$$

と表される. 受音点位置 $x$ に応じて変化するのは $G \mathrm{~ms}{ }_{-} s_{t}$ のみであり, 無限級数の公比 $\gamma_{1} \gamma_{\mathrm{r}} e^{-2 j \omega l o / c}$ は 一定の值をとる. 従って公比 $\gamma_{1} \gamma_{\mathrm{r}} e^{-2 j \omega l o / c}$ を測定に より得られれば，任意の $x$ での $G_{\mathrm{ms} \text { _ } 1 s t}$ を補間し式(15) に代入することにより $x$ での伝達関数 $G \mathrm{~ms}$ を求められ る. これが今回提案する、インパルス応答を用いた伝 達関数補間法の基本原理である. 以下に無限級数の公

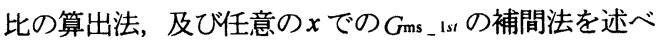
る.

伝達関数 $G \mathrm{~ms}(j \omega)$ のインパルス応答 $g_{\mathrm{ms}}(t)$ を音響管 1 往復時間 $2 l_{0} / c$ で区切ったとき, 図 4 に示す最初の 1 区間の波形 $g_{\mathrm{ms} \text { _lst }}(t)$ は $G \mathrm{~ms} \_$Ist $(j \omega)$ のインパルス応答であ る. $g_{\mathrm{ms} \_ \text {st }}(t)$ の 4 個のインパルスがそれぞれ両端で反 射し管内を 1 往復したものが図 4 の $g_{\mathrm{ms} \_2 n d}(t)$ である. $g_{\mathrm{ms} \_ \text {Ist }}(t)$ と $g_{\mathrm{ms} \_ \text {nd }}(t)$ を分離した上で，それぞれフーリ 工変換して得た $G \mathrm{~ms} \_1 \mathrm{st}(j \omega), G \mathrm{~ms} \_2 \mathrm{nd}(j \omega)$ を用いて式

$$
H_{\mathrm{ms} \_l}=\frac{G_{\text {ms_2nd }}}{G_{\text {ms_lst }}}
$$

から得た $H_{\mathrm{ms} \_}$を伝達関数 $G_{\mathrm{ms}}$ における無限級数の公比 と定義する. 

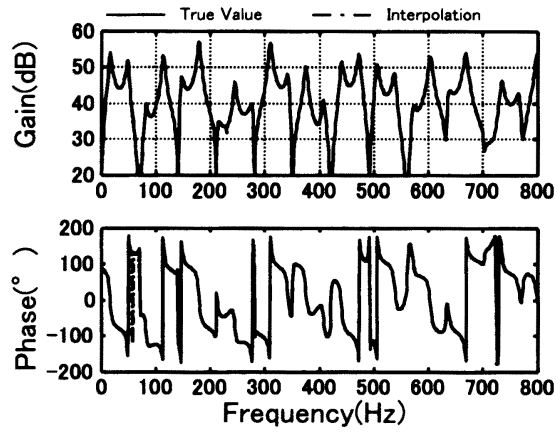

Fig. 7 Comparison of transfer functions at point B.

次に $g_{\mathrm{ms} \_ \text {st }}(t)$ の補間法を述べる. 図 2 の A, B, C各

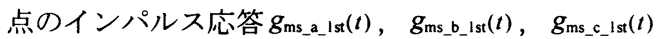
を図 6 に示す．各インパルスは受音点位置に応じた時 間遅れを持つので， $g_{\mathrm{ms} \_ \text {_blst }}(t)$ の最初のインパルス(1) ${ }^{\mathrm{B}}$ は $g_{\mathrm{ms} \_ \text {__lst }}(t)$ 及び $g_{\mathrm{ms} \_ \text {__lst }}(t)$ の最初のインパルス(1) 及び (1) $)^{\mathrm{C}}$ の間を $\left(x_{\mathrm{b}}-x_{\mathrm{a}}\right):\left(x_{\mathrm{c}}-x_{\mathrm{b}}\right)$ に内分する位置にある. $g_{\text {ms_b_lst }}(t)$ にある他 3 個のインパルスについても同様 である．任意の $x$ についも同様に， $x$ を挟むように 2 箇所の伝達関数測定点をとることで，測定された 2

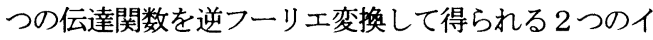
ンパルス応答の波形と 3 点の位置関係より $x$ における $g_{\mathrm{ms} \_\mathrm{st}}(t)$ が補間できる。

$g_{\mathrm{ms} \_ \text {b_lst }}(t)$ をフーリエ変換して得られる $G$ ms_b_lst $(j \omega)$ と，先ほど求めた無限級数の公比 $H_{\mathrm{ms} \_1}$ から式

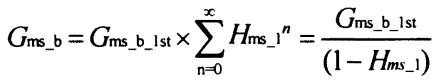

によって B 点での伝達関数 $G$ ms。 が得られる.こうし て得た $G$ ms_b の補間值を式(9)より得た值と図 7 に比較 するが，両者は極めて良く一致し，この伝達関数補間 法の妥当性を確認できる.

23 実㰸装国及び結果図 2 に示す実験に用いた音 響管の諸元は, 表 1 に示す数値計算に用いた諸元と同 じ值である.ただし $\rho, c お よ ひ ゙ \gamma_{1}$ は未知でも補間に は差し支えないので測定していない. なお音響管には 塩化ビニル管を用い，左端には吸音材としてグラスウ 一ルを貼り右端は開放端とした。 また, 音源表面速度 乡゙はスピーカーのコーンに貼り付けた加速度ピックア ップで測定した.

入力信号に掃引正弦波を用いて $\dot{\xi}_{\mathrm{s}}$ とマイクロホン音 圧 $P$ 間の伝達関数 $G_{\mathrm{ms}}(j \omega)$ を測定し, 逆フーリエ変換 によりインパルス応答 $g_{\mathrm{ms}}(t)$ を求めた。 $\mathrm{A}$ 点での測定 から得られた $g_{\text {ms_a_lst }}(t) ， g_{\text {ms_a_nd }}(t)$ をそれぞれフーリ 工変換して得た $G_{\text {ms_a_lst }}(j \omega) ， G_{\text {ms_a_znd }}(j \omega)$ から式(16)に よって得た $\mathrm{H}_{\mathrm{ms} \_1}(j \omega)$ を図 8 に示す，音響管の共振・反
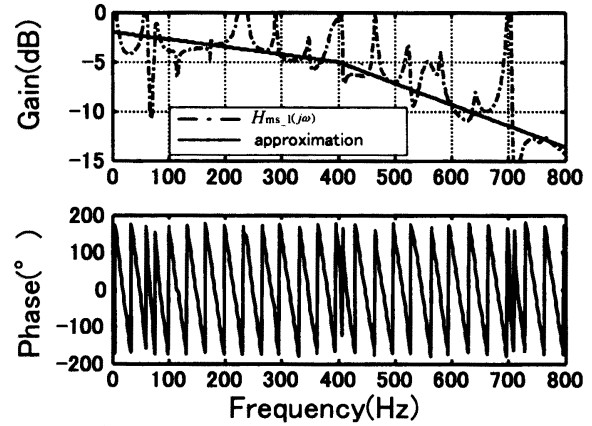

Fig. 8 Transfer function calculated from the first 8 impulses.

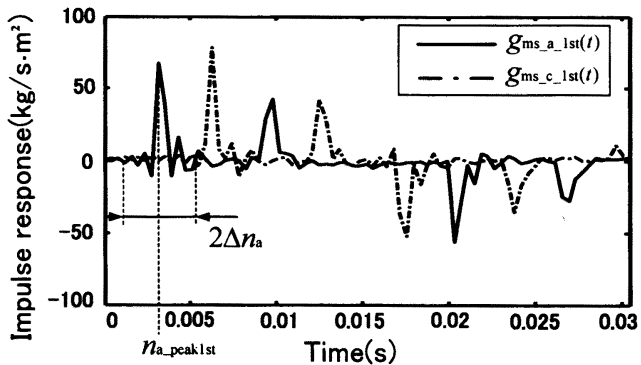

Fig. 9 Impulse responses measured at point $\mathrm{A}$ and $\mathrm{C}$.

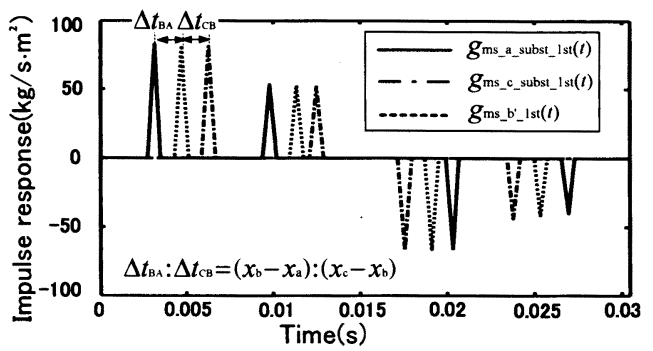

Fig. 10 Interpolation of impulse response at point B (Experiment).

共振点においてゲインに変則的な突起が見られる. そ こで今後の計算には同図の実線で示す近似值を用いた。 C 点で測定した $G_{\mathrm{ms}} \mathrm{c}(j \omega)$ から同様にして得た

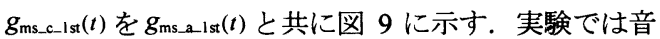
速とサンプリング時間の積で定まる距離と実際の音圧 測定位置が完全には一致しないため，インパルス応答 の波形は純粋なインパルスの形状から歪む. そこで 各インパルスのピーク位置 $g\left(n_{\text {peak }}\right)$ から $\pm \Delta n$ の範囲に エネルギーが分散したと見なし，総和

$$
E_{\text {peak }}=\sum_{n \text { peak }-v n}^{n_{\text {peak }}+v n}\left(g_{\mathrm{ms}}(n)\right)^{2}
$$

を求め, $g_{\mathrm{ms} \_ \text {_l } 1 \mathrm{st}}(t), g_{\mathrm{ms} \_ \text {__lst }}(t)$ の各インパルスを大き さ $\sqrt{E_{\text {peak }}}$ の幅のないインパルスで置き換える. 置き換 

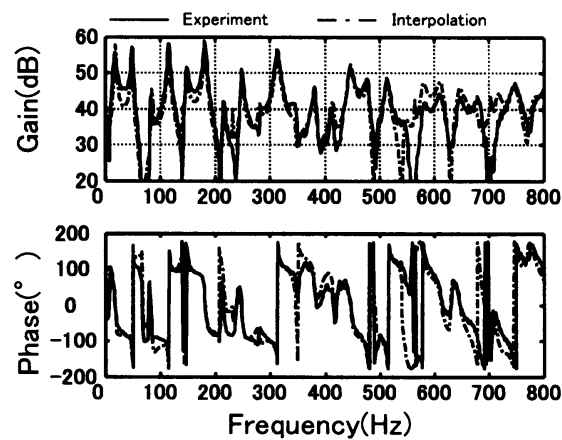

Fig. 11 Interpolated transfer function at point B (Experiment).

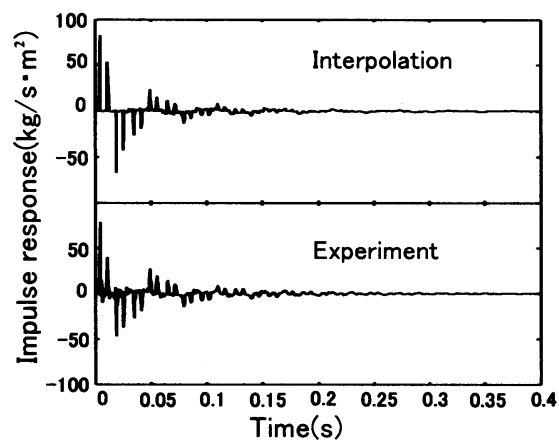

Fig. 12 Interpolated impulse response at point B (Experiment).

えた波形 $g_{\text {ms_a_subst_lst }}(t) ， g_{\text {ms_c_subst_lst }}(t)$ を図 10 に示す. なお $\Delta n=5$ とした.

$g_{\text {ms_a_subst_lst }}(t), \quad g_{\text {ms_c_subst_lst }}(t)$ 両者の各インパルスの 間隔を $\left(x_{\mathrm{b}}-x_{\mathrm{a}}\right):\left(x_{\mathrm{c}}-x_{\mathrm{b}}\right)$ に内分する点に最も近い $\Delta t$ の 倍数の位置にインパルスを置く事で, $\mathrm{B}$ 点での補間值 $g_{\mathrm{ms} \_b '-1 \mathrm{st}}(t)$ を得る. $\Delta t$ の倍数にとるのは, サンプリン グされた時間波形は離散化され $\Delta t$ おきにのみ值を持 つためである. なお $g_{\mathrm{ms}-b^{\prime}-1 \mathrm{st}}(t)$ の各インパルスの大き さ $\sqrt{E_{\text {peak_b }}}$ は, $g_{\text {ms_a_subst_lst }}(t)$ 及び $g_{\text {ms_c_subst_lst }}(t)$ の各イン パルスの大きさ $\sqrt{E_{\text {peak_a }}}, \sqrt{E_{\text {peak_c }}}$ から式

$$
\begin{aligned}
& \sqrt{E_{\text {peak_b }}}-\sqrt{E_{\text {peak_a }}}: \sqrt{E_{\text {peak_c }}}-\sqrt{E_{\text {peak_b }}} \\
& =\left(x_{\mathrm{b}}-x_{\mathrm{a}}\right):\left(x_{\mathrm{c}}-x_{\mathrm{b}}\right)
\end{aligned}
$$

を満たすように定めた． $g_{\text {ms_b'-1st }}(t)$ をフーリエ変換し

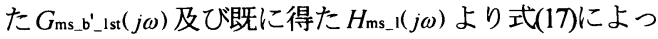
て $G_{\mathrm{ms} \_b}(j \omega)$ を得る. $G_{\mathrm{ms} \_} \mathrm{b}^{\prime}(j \omega)$ およびそのインパルス 応答 $g_{\mathrm{ms} \_b}(t)$ と B 点での測定值 $G_{\mathrm{ms} \_\mathrm{b}}(j \omega)$ および $g_{\mathrm{ms} \_\mathrm{b}}(t)$ との比較を図 11,12 に示す. $G_{\mathrm{ms} \_b}(j \omega)$ と $G_{\mathrm{ms} \_} \mathrm{b}^{\prime}(j \omega)$ は $f=800 \mathrm{~Hz}$ まで良く一致しており，また $g_{\mathrm{ms} \_\mathrm{b}}(t)$ と $g_{\mathrm{ms} \_} \mathrm{b}^{\prime}(t)$ も良い一致を示す.

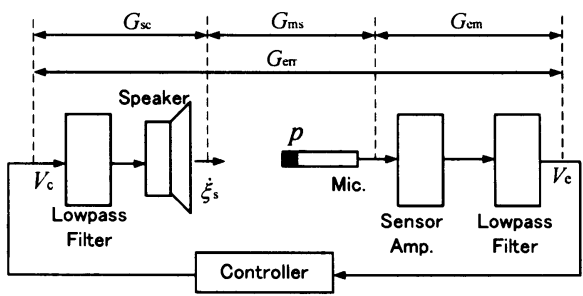

Fig. 13 Block diagram of transfer function of the error path.
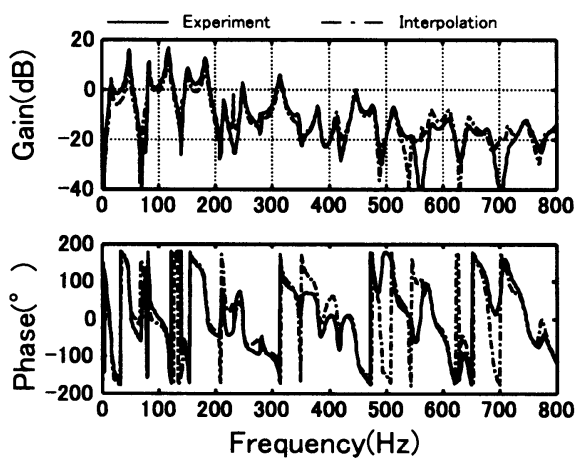

Fig. 14 Interpolated transfer function of the error path.

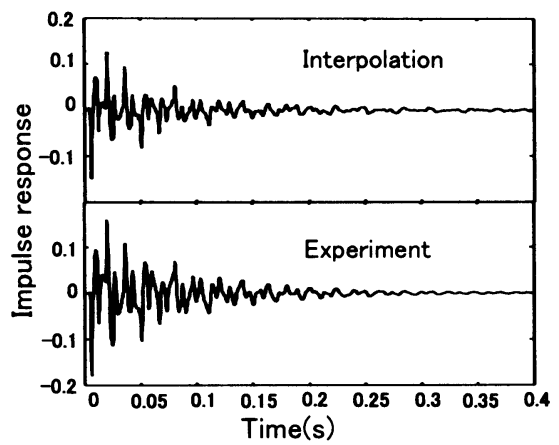

Fig. 15 Interpolated impulse response of the error path.

\section{3. 誤差経路伝连関数の} 可变成分と不变成分の分噰

第 2 章において提案した伝達関数補間法の対象は, 音源表面の振動速度 $\dot{\xi}$,とマイクロホン音圧 $P$ 間の伝達 関数 $G \mathrm{~ms}$ であった. 能動騒音制御において制御器に対 する制御音源及び受音点の接続は図 13 に示すように 複数の機器が介在するため, 制御器からの制御信号 $V_{\mathrm{c}}$ と制御器への誤差信号 $V_{\mathrm{e}}$ 間の誤差経路伝達関数 $G_{\mathrm{cr}}$ は式

$G_{\mathrm{crr}}=G_{\mathrm{sc}} \cdot G_{\mathrm{ms}} \cdot G_{\mathrm{cm}}$ 


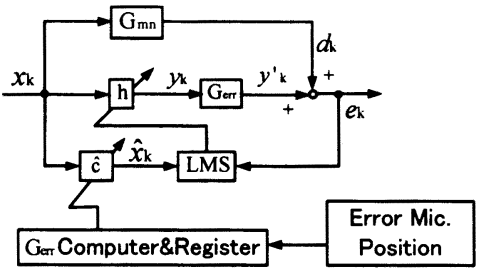

Fig. 16 Block diagram of FF with change of the Interpolation value of TFEP.

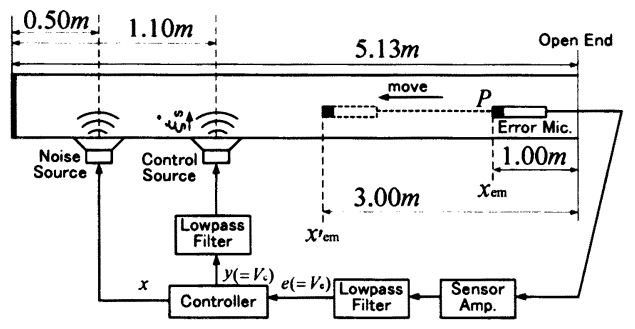

Fig. 17 Schematic diagram of ANC system in numerical simulation.

と表される. $G_{\mathrm{sc}}$ は制御信号 $V_{\mathrm{c}}$ と安間の伝達関数, $G_{\mathrm{em}}$ は $P$ と誤差信号 $V_{\mathrm{e}}$ 間の伝達関数である. ローパ スフィルタは能動騒音制御が低周波領域のみを対象と するために入れている. このうちマイクロホン位置に 応じて変化するのは $G_{\mathrm{ms}}$ のみであり, $G_{\mathrm{sc}}$ 及び $G_{\mathrm{em}}$ は不 変である. 従って図 2 の $\mathrm{A}, \mathrm{C}$ 点で測定した $G_{\mathrm{ms}} \mathrm{a}$, $G_{\mathrm{ms}}$ 加第 2 章で示した補間法によって B 点での $G_{\mathrm{ms} \text { b }}$ を補間することで，予め測定しておいた $G_{\mathrm{sc}}$ 及び $G_{\mathrm{em}}$ から式(20)によって B 点での誤差経路伝達関数 $G_{\text {err_b }}$ が得られる. 図 14 に示すように $f=800 \mathrm{~Hz}$ まで $G_{\text {err_b }}(j \omega)$ の補間値は測定值と良く一致し, 逆フーリエ 変換によって得たインパルス応答 $g_{\mathrm{er} \_b}(t)$ も図 15 に示 すように測定值と良い一致を示す.

\section{4. 受音点が移功する際の能功音制御}

図 16 に今回提案する, 誤差経路伝達関数の変化に 従う補償フィルタ更新法のブロック線図を示す. 図中 $x, y, e, d$ はそれぞれ参照信号, 制御信号, 誤差 信号，騒音を表す．また本論文では以降各信号におけ る添字 $k$ でサンプリング番号を表す， $G_{\mathrm{err}}$ は式(20)で表 される誤差経路伝達関数， $G_{\mathrm{mn}}$ は参照信号・誤差信号 間の伝達関数, $\hat{C}$ は $G_{\text {err }}$ を補償するためのフィルタ， $\mathrm{h}$ は騒音制御のための主系フィルタである.

数箇所の適当なエラーマイクロホン位置 $x_{\mathrm{em}}$ におい て $G_{\mathrm{crr}}$ を測定することで, 前述の伝達関数補間法によ って任意の $x_{\mathrm{em}}$ における $G_{\mathrm{err}}$ は予め同定できる. 今回 提案する方法では騒音制御中に $x_{\mathrm{em}}$ を常に測定し，そ の位置に対応した $G_{\mathrm{er}}$ に基づいて $\hat{C}$ を更新して能動騒

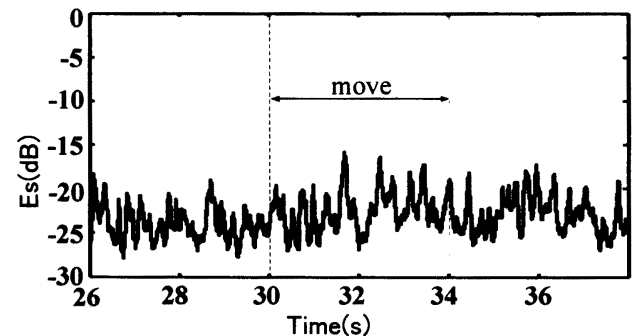

Fig. 18 Performance of noise reduction in numerical simulation.

音制御を行なう。この場合， $G_{\text {err }}$ を補間するマイクロ ホン位置の間隔は補間法の原理上 $c \Delta t$ おきとならざる を得ないが, 任意の位置において与える $G_{\text {err }}$ はその位 置から $\pm c \Delta t / 2$ 以下だけ離れた位置での $G_{\mathrm{err}}$ の值とな るので, 同定精度は常に一定水準以上を保つ.

4.1 数值計篎 図 17 に示す 1 次元音響管における能 動騒音制御の数值計算を行なった. 制御器出力 $V_{\mathrm{c}}$ と 音源振動速度 $\dot{\xi}_{\mathrm{s}}$ 間の伝達関数 $G \mathrm{sc}$ 及び音圧 $P$ と誤差信 号 $V_{\mathrm{e}}$ 間の伝達関数 $G_{\mathrm{em}}$ は第 4 章での測定值を用いた.

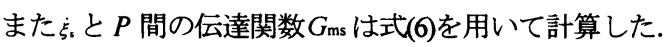
サンプリング周波数 $f_{\mathrm{s}}=2560 \mathrm{~Hz}$, 各伝達関数はタッ プ数 256 の FIR フィルタで模擬した. 騒音制御の主系 フィルタ $\mathrm{h}$ 及び補償フィルタ $\hat{\mathrm{c}}$ は共にタップ数 $\mathrm{M}=256$ の FIR フィルタとした. また収束性を高める 為に適応アルゴリズムは LMS の代わりに学習同定法 (normalized LMS) を採用した ${ }^{(8)}$. 主系フィルタ更新に 用いるステップサイズパラメータの值は $\mu_{h}=0.5$ と した.

制御性能の評価には制御時における誤差信号 $e_{\mathrm{c}}$ の $l$ サンプルごとの二乗平均を非制御時の誤差信号 $e_{\mathrm{nc}}$ の 二乗平均により正規化した值

$$
E_{\mathrm{s}}(k)=10 \log _{10}\left\{\frac{\sum_{k=n}^{n+1} e_{\mathrm{c}}^{2}(k)}{\sum_{k=n}^{n+1} e_{\mathrm{nc}}^{2}(k)}\right\}
$$

を用いた。

エラーマイクロホンは $x_{\mathrm{em}}$ から $x_{\mathrm{em}}^{\prime}$ まで移動するも のとし,$x_{\mathrm{em}}$ および $x_{\mathrm{em}}^{\prime}$ における $G_{\mathrm{ms}}$ の計算值から $x_{\mathrm{em}}$ と $x^{\prime}{ }_{\mathrm{em}}$ の間の各位置における $G_{\mathrm{ms}}$ の值を $c \Delta t=0.13 \mathrm{~m}$ の 間隔で補間し，式(20)より各位置での $G_{\mathrm{err}}$ を得た．エ ラーマイクロホンの移動中は， $G_{\mathrm{err}}$ の補間值が得られ ている位置の中で現在のエラーマイクロホン位置に最 も近い位置での $G_{\mathrm{err}}$ の補間值を元に補償フィルタ $\hat{C} を$ 更新した.

能動騒音制御を開始した時点を $t=0(s)$ とおき, $t=30(s)$ までエラーマイクロホンを $x_{\mathrm{em}}$ で固定した状 


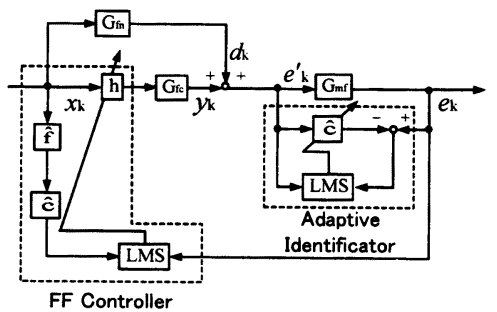

Fig. 19 Block diagram of FF with fixed microphone and adaptive identificator.

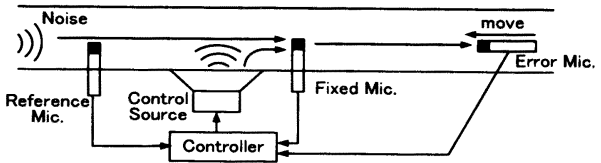

Fig. 20 Schematic diagram of FF with fixed microphone and adaptive identificator.

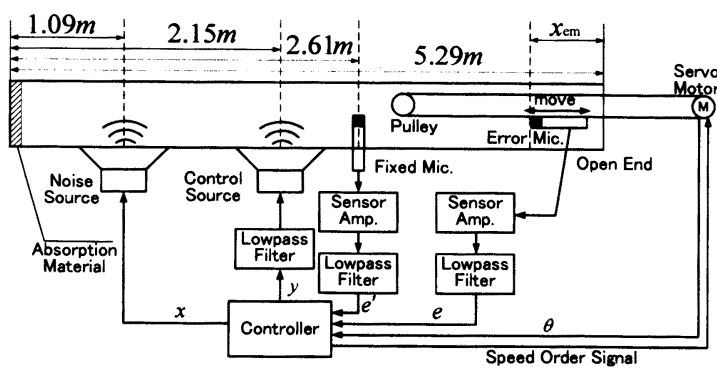

Fig. 21 Experimental apparatus of the ANC system.

態で制御を行ない十分消音された後に, 騒音源へ向け 速度 $0.5 \mathrm{~m} / \mathrm{s}$ で $x_{\mathrm{em}}^{\prime}$ まで 4 秒間移動させ, $x_{\mathrm{em}}^{\prime}$ で再ひ清争 止させ制御を続けた。

$26 \leq t \leq 38$ の $E_{\mathrm{s}}(k)$ を図 18 に示す．移動中，実際の $G_{\mathrm{mc}}$ は連続的に変化するが補償フィルタ $\hat{C}$ の更新は $c \Delta t=0.13 m$ 間隔で段階的に行なわれた。 しかしエラ 一マイクロホン固定時に比べ消音性能の悪化は殆ど見 られずこの制御法の妥当性が示されている.

4.2 站差経路伝達関数の实時间同定による制御従 来提案されているフィルタ更新法の基本的なブロック 線図を図 19 に示す ${ }^{(4)}$. これは図 20 に示すように移動 するエラーマイクロホンとは別に固定マイクロホンを 制御音源の近くに置き, 固定マイクロホンからの信号 $e^{\prime}$ とエラーマイクロホンからの誤差信号e の伝達関数 $G_{\mathrm{mf}}$ の変化を実時間同定し, それに基づきフィードフ オワード制御部の補償フィルタ $\hat{\mathrm{C}}$ 逐次更新するもの である. なお， $G_{\mathrm{fn}}$ は参照信号・固定マイクロホン間, $G_{\mathrm{fc}}$ は制御信号・固定マイクロホン間の伝達関数であ り, $\hat{\mathrm{f}}$ は $G_{\mathrm{fc}}$ を補償するフィルタ（固定）である.

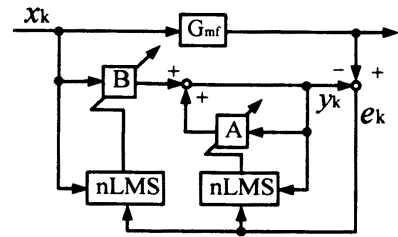

Fig. 22 Block diagram of error path identificator with IIR filter.

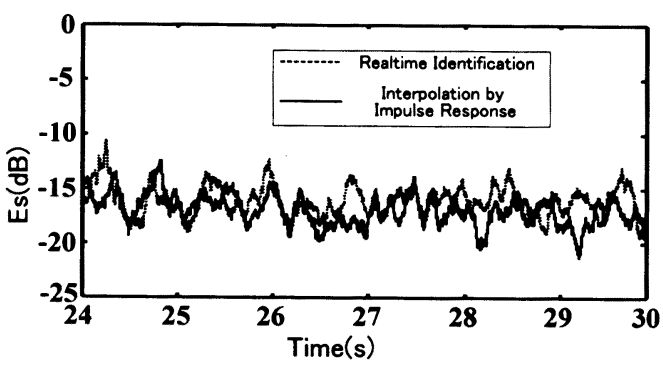

Fig. 23 Comparison of the conventional realtime identification system and the proposed interpolation system when error microphone is fixed.

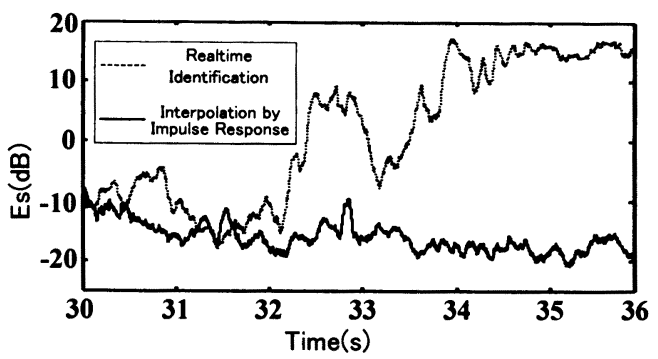

Fig. 24 Comparison of the conventional realtime identification system and the proposed interpolation system when error microphone moves.

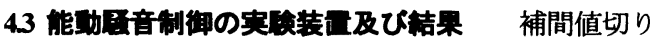
替えによる能動騒音制御の有効性が数値計算により示 されたので，実験による検証を行ない，実時間同定に よる従来の制御と比較した，実験に用いた装置を図 21 に示す。制御器には dSPACE 社製 DSP の DS1 104 を 用い, 制御プログラムは mathworks 社のソフトウェア MATLAB 及び Simlink で作製・実装した．音響管には 第 2 章の実験と同じ塩化ビニル管を用い，右端は開放 端とし，左端には吸音材としてグラスウールを貼った。 固定マイクロホンからの信号 $e^{\prime}$ は $G_{\mathrm{mf}}$ 実時間同定によ る制御のみに用い，またサーボモータからの回転角信 号 $\theta$ （マイクロホン位置と対応）は $G_{\mathrm{err}}$ 補間値切り替 えによる制御のみに用いた。 またハウリングなどの影 
響を極力避けるため, 参照信号 $x$ は騒音源への入力信 号をそのまま利用した.

変動する $G_{\mathrm{mf}}$ の実時間同定部は, 高速化と収束性向 上の為, FIRフィルタに代わり式

$$
y_{\mathrm{k}}=\sum_{m=1}^{\mathrm{M}_{\mathrm{A}}} A_{m} y_{k-m}+\sum_{n=0}^{M_{\mathrm{B}}} B_{n} x_{k-n}
$$

で表される IIR フィルタを導入した(5). ブロック線図 を図 22 に示す. タップ長は $\mathrm{MA}_{\mathrm{A}}=40, \mathrm{MB}=32$ とした. 式(22)の各フィルタ係数更新式は

$$
\begin{aligned}
& A_{k+1}=A_{k}+\alpha_{\mathrm{A}} \frac{x_{k}}{\left\|x_{k}\right\|^{2}+\left\|y_{k}\right\|^{2}} e_{k} \\
& B_{k+1}=B_{k}+\alpha_{\mathrm{B}} \frac{y_{k}}{\left\|x_{k}\right\|^{2}+\left\|y_{k}\right\|^{2}} e_{k}
\end{aligned}
$$

である. ステップサイズパラメータ $\alpha_{\mathrm{A}}, \alpha_{\mathrm{B}}$ の大きさ は共に5.0×10-2 とした.

まず移動させる前に図 21 の $x_{\mathrm{em}}=0.63 \mathrm{~m}$ の位置にエ ラーマイクロホンを固定した状態で 30 秒間制御を行 なった。制御開始時を $t=0(s)$ とし， $24 \leq t \leq 30$ の $E_{\mathrm{s}}(k)$ を誤差経路実時間同定による制御, 補間値切り 替えによる制御共に図 23 に示す。なお，両者共に主 系フィルタ $h$ のップ数 $\mathrm{M}=128$, ステップサイズパ ラメータは $4.0 \times 10^{-2}$ である. 共に約 $16 \mathrm{~dB}$ の安定した 消音が行なわれている.

$t=30(\mathrm{~s})$ からエラーマイクロホンを約 $0.5 \mathrm{~m} / \mathrm{s}$ で騒音 源側に 2.9 秒間移動させ再び静止させた. $30 \leq t \leq 36$ の $E_{\mathrm{s}}(k)$ を 2 者の制御法共に図 24 に示す．両者共に移 動開始時に消音性能が約 $10 \mathrm{~dB}$ 低下し， $G_{\mathrm{mf}}$ を実時間 同定する制御はやがて不安定となり発散する. 一方, 補間により予め同定した $G_{\mathrm{err}}$ を $x_{\mathrm{em}}$ に応じて補償フィ ルタに逐次与える制御では移動中及び移動終了後も安 定した消音が行なわれている.

\section{5. 結吾}

本研究では受音点が移動することで伝達関数が変化 する 1 次元音場での能動騒音制御について研究し, 以 下の結論を得た.

1. 平面波を前提に, ある測定点でのインパルス応 答より任意点での伝達関数を補間する方法を提 案した，補間された值は，測定値と良く一致す る.

2. 評価点が移動する系での能動騒音制御において, 各位置での伝達関数を本提案の補間法で同定し それを補償フィルタにリアルタイムで与える制 御法を提案した。この制御法は安定した消音性 能を実現することが実験により検証された。
(1) B. widrow and S. D. Streans, Adaptive signal processing, Prentice-Hall Inc., Englewood Cliffs, (1985)

(2) 佐野・ほか 2 名, フィードバック制御に IMCを用 いた 2 自由度型アクティブ騒音制御に関する研究, 日本機械学会論文集 $(\mathrm{C}$ 編)63 巻 608 号, (1997), pp. 1208-1213

(3) 中井・ほか 2 名, アクティブノイズ制御系への二 自由度制御手法の適用, 日本機械学会論文集 $(\mathrm{C}$ 編)63 巻 608 号, (1997), pp. 1214-1220

(4) 小池 - ほか 3 名, 評価点の移動する 1 次元音場内 の能動的音響制御（第 1 報, 評価点の移動に対応 可能な音響制御器の提案)，日本機械学会論文集 (C編)67巻 654号, (2001), pp. 321-328

(5) 小池 - ほか 3 名, 評価点の移動する 1 次元音場内 の能動的音響制御（第 2 報, 評価点の高速な移動 に対応した音響制御器の提案)，日本機械学会論 文集(C編)67巻 660 号, (2001), pp. 2521-2527

(6) 鈴木・本郷，能動制御における二次音源に関する 考察, 電子情報通信学会技術研究報告. EA, 応用音 響96巻 437号, (1996), pp. 31-37

(7) 鈴木・ほか 2 名, 反射成分を考慮した音響管騒音 能動制御のフィルタ特性に関する考察, 日本音響 学会誌 51 巻 5 号, (1995), pp. 341-348

(8) J. Nagumo and A.Noda, A Learning Method for System Identification, IEEE Trans. Autom. Control, AC-12, No. 3, (1967), pp. 282-287

\section{6. 考文献}

